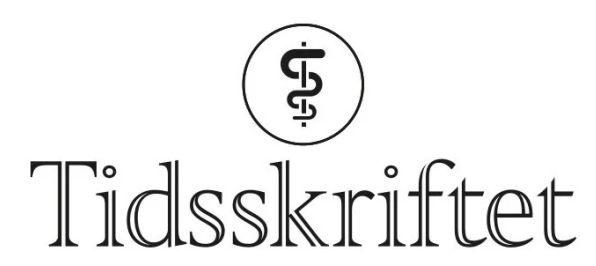

DEN NORSKE LEGEFORENING

\title{
Misforstått om viktig maktanalyse
}

\author{
BREV TIL REDAKTØREN
}

\section{GEORG ESPOLIN JOHNSON}

Georg Espolin Johnson (f. 1953) er cand.med. og cand.philol. med idéhistorie hovedfag på en oppgave om legerollen som historisk konstruksjon. Han har yrkeserfaring fra allmennmedisin, arbeidsmedisin, personforsikring og trygdemedisin. Han er medisinskkyndig rettsmedlem i Trygderetten (trygderettsdommer) og har bistilling som universitetslektor ved Institutt for helse og samfunn, Avdeling for samfunnsmedisin. Ingen oppgitte interessekonflikter. Trygderetten i Oslo

Oddbjørn Brubakks leserinnlegg i Tidsskriftet nr. 8/2012 (1) føyer seg inn i det jeg oppfatter som misforstått kritikk av Tidsskriftets relevante og viktige påpekning av at andre forhold enn kvalitet og klinisk relevans bidrar til å avgjøre hvilke utgivelser som fenger og oppnår publisitet i samfunnet.

I sin leder i Tidsskriftet nr. 2/2012 (ㅁ) setter Stine Bjerkestrand verken metode eller resultater i to artikler om kronisk utmattelsessyndrom opp mot hverandre. Hun tar heller ikke stilling til teorier om tilstanden, men påpeker at utenomfaglige krefter påvirker hvilken oppmerksomhet som blir forskningen til del.

Fordi hun har valgt en kontroversiell klinisk tilstand som eksempel, har dessverre temaet druknet i en metadiskusjon om årsak og behandling (3). Etter mitt syn er det Brubakk og øvrige kritikere som viser at de har tatt stilling i sistnevnte debatt når de har gått glipp av Bjerkestrands egentlige poeng.

Som eksempel på Bjerkestrands tematikk vil jeg vise til en artikkel i et av de siste numrene av Lancet om effekten av Internett-basert kognitiv terapi ved kronisk utmattelsessyndrom hos barn og unge i alderen 12-18 år (4). Resultatene var oppsiktsvekkende gode i intervensjonsgruppen sammenliknet med resultatene i kontrollgruppen. Studien er omtalt i Dagens Medisin og således gjort kjent for et langt bredere publikum enn Lancetleserne, inkludert bloggere og helsejournalister. Jeg kan vanskelig forstå at denne studiens resultater skulle være mindre klinisk relevante enn rituximabstudiens, uten på noen måte å sette dem kvalitetsmessig opp mot hverandre. Poenget i denne sammenhengen er at andre forhold enn kvalitet og klinisk relevans belyser hvorfor den ene studien har fått mer oppmerksomhet enn den andre.

Jeg skulle ønske vi kunne enes om at årsaksbildet ved kronisk utmattelsessyndrom er uklart og sammensatt, at patogenesen er interessant, men ikke nødvendigvis relevant for behandlingen, og at kognitiv terapi har effekt når den blir godt tilrettelagt. Men, som Bjerkestrand påpeker, vi bør først og fremst enes om at hvilken forskning som pønskes ut, iverksettes, finansieres og stimuleres, og hvilke resultater som fenger i samfunnet, i stor 
grad styres av forventet oppmerksomhet. Denne oppmerksomheten er i sin tur ikke først og fremst bestemt av hva som er klinisk relevant, men av samfunnets mottakelighet - av hva som er in og salgbart.

Virkelig nøytral forskning og forskningsformidling er en illusjon. Når vi likevel streber mot dette idealet, må vi ta hensyn til alle mekanismer som er i sving. Det er bekymringsfullt at så mange norske leger ikke synes å forstå hvilken makt som ligger i de ukontrollerte, vanskelig tilgjengelige, ikke-målrettede, ikke-totalitære og ikke-ondsinnede, men likevel svært sterke og sorterende samfunnskreftene.

\section{LITTERATUR}

1. Brubakk O. To underlige lederartikler. Tidsskr Nor Legeforen 2012;132: 927. [PubMed]

2. Bjerkestrand S. Maktskiftet. Tidsskr Nor Legeforen 2012; 132: 125. [PubMed]

3. Bjerkestrand S. Nødvendig maktskifte? Tidsskr Nor Legeforen 2012; 132: 619. [PubMed]

4. Nijhof SL, Bleijenberg G, Uiterwaal CS et al. Effectiveness of internet-based cognitive behavioural treatment for adolescents with chronic fatigue syndrome (FITNET): a randomised controlled trial. Lancet 2012; 379: 1412-8. [PubMed] [CrossRef]

Publisert: 26. juni 2012. Tidsskr Nor Legeforen. DOI:10.4045/tidsskr.12.0585

(C) Tidsskrift for Den norske legeforening 2023. Lastet ned fra tidsskriftet.no 26. april 2023. 